\title{
Teknik Pembuatan Herbarium Bagi Siswa SMA Negeri 1 Pangkalan Lampam Kabupaten Ogan Komering Ilir
}

Inka Dahlianah $^{1}$, Syaiful Eddy ${ }^{2}$, Dewi Rosanti ${ }^{3}$, Ita Emilia ${ }^{4}$, Yunita Panca Putri ${ }^{5}$, Dwi Warsari ${ }^{6}$

${ }^{1-6}$ Program Studi Biologi (S1), Fakultas Sains dan Teknologi, Universitas PGRI Palembang

e-mail: ${ }^{1}$ dwrosanti@gmail.com

\begin{abstract}
ABSTRAK Sistematika tumbuhan merupakan suatu bidang studi yang luas yang mencakup keanekaragaman, identitifikasi, penamaan, klasifikasi, dan evolusi tumbuhan. Istilah lain untuk sistematika tumbuhan adalah taksonomi tumbuhan, oleh karena itu beberapa ilmuwan menyatakan bahwa sistematika tumbuhan dan taksonomi tumbuhan merupakan sinonim. Taksonomi tumbuhan merupakan teori dari klasifikasi tumbuhan. Jadi dengan demikian taksonomi merupakan bagian dari sistematika tumbuhan, yang mencakup prinsip, prosedur, peraturan, dan dasar dari klasifikasi tumbuhan. Tujuan mempelajari taksonomi tumbuhan adalah menginventarisasi tumbuhan yang ada di dunia, memberikan metode untuk identifikasi dan komunikasi, menghasilkan sistem klasifikasi yang terpadu dan universal, memberikan nama ilmiah dalam bahasa latin untuk setiap kelompok tumbuhan yang ada di bumi, baik yang masih hidup maupun yang sudah fosil dan menunjukkan implikasi evolusi dari keanekaragaman tumbuhan. Metode pelaksanaan melalui kegiata penyuluhan dan pelatihan yang dapat diwujudkan dalam satu kegiatan inti yaitu membuat herbarium. Sehingga, di era pandemi Covid-19 ini, herbarium dapat dijadikan sebagai media entrepreneur.
\end{abstract}

\section{KATA KUNCI: taksonomi; herbarium; entrepreneur}

ABSTRACT Plant systematics is a broad field of study that includes diversity, identification, naming, classification, and plant evolution. Another term for plant systematics is plant taxonomy, therefore some scientists state that plant systematics and plant taxonomy are synonyms. Plant taxonomy is a theory of plant classification. So thus taxonomy is part of plant systematics, which includes principles, procedures, rules, and the basis of plant classification. The purpose of studying plant taxonomy is to take an inventory of plants in the world, provide methods for identification and communication, produce an integrated and universal classification system, provide scientific names in Latin for each group of plants on earth, both living and fossilized. and demonstrate the evolutionary implications of plant diversity. The method of implementation through counseling and training activities that can be realized in one core activity is to make herbarium. So, in the era of the Covid-19 pandemic, herbarium can be used as a media entrepreneur.

KEYWORDS : taxonomy; herbarium; entrepreneur

\section{Pendahuluan}

Taksonomi merupakan dasar untuk disiplin ilmu lain seperti: anatomi, sitologi, palinologi, embriologi, genetika, fisiologi, biokimia, ekologi, geografi, paleobotani, dan morfologi. Dalam perkembangannya taksonomi ditunjang oleh disiplin-disiplin ilmu tersebut. Bukti-bukti taksonomi diperoleh dari data-data yang diberikan oleh disiplin-disiplin ilmu tersebut. Aspek-aspek atau pendekatan-pendekatan dalam sistematika/taksonomi meliputi taksonomi tradisional sifat-sifat kimia dari tumbuhan dalam pengembangan klasifiksi, taksonomi modern atau biosistematik dan taksonomi numeric berupa pengolaaan berbagai data taksonomi secara matematik bahkan dengan bantuan komputer. 
Dalam menerapkan ilmu taksonomi, biasanya diiringi dengan pembuatan herbarium (Rosanti, 2012).[1] Persiapan koleksi yang baik di lapangan merupakan aspek penting dalam praktek pembuatan herbarium. Spesimen herbarium yang baik harus memberikan informasi terbaik mengenai tumbuhan tersebut kepada para peneliti. Dengan kata lain, suatu koleksi tumbuhan harus mempunyai seluruh bagian tumbuhan dan harus ada keterangan yang memberikan seluruh informasi yang tidak nampak pada spesimen herbarium. Hal-hal yang perlu diperhatikan dalam mengkoleksi tumbuhan antara lain: perlengkapan Beberapa perlengkapan yang diperlukan untuk mengkoleksi tumbuhan di lapangan antara lain: gunting tanaman, buku catatan, label, pensil, lensa tangan, Koran bekas, penekan/penghimpit, tali pengikat, vasculum, kantong plastik, alkohol, kantong kertas (untuk cryptogamae, buah dan biji), peta, kamera dan sebagainya.

Tumbuhan kecil harus dikoleksi seluruh organnya. Tumbuhan besar atau pohon, dikoleksi sebagian cabangnya dengan panjang $\mathrm{cm}$ yang mempunyai organ lengkap: daun (minimal punya 3 daun untuk melihat phylotaksis), bunga dan buah, diambil dari satu tumbuhan. Untuk pohon yang sangat tinggi, pengambilan organ generatifnya bisa dilakukan dengan galah, ketapel atau menggunakan hewan, misalnya beruk. Untuk pohon atau perdu kadang-kadang penting untuk mengkoleksi kuncup (daun baru) karena kadang-kadang stipulanya mudah gugur dan brakhtea sering ditemukan hanya pada bagian-bagian yang muda. Tumbuhan herba dikoleksi seluruh organnya kecuali untuk herba besar seperti Araceae. Koleksi tumbuhan hidup, dianjurkan untuk ditanam di kebun botani dan rumah kaca.

Catatan lapangan segera dibuat setelah mengkoleksi tumbuhan, berisi keterangan-keterangan tentang ciri-ciri tumbuhan tersebut yang tidak terlihat setelah spesimen kering. Beberapa keterangan yang harus dicantumkan antara lain: lokasi, habitat, habit, warna (bunga, buah), bau, eksudat, pollinator (kalau ada), pemanfaatan secara lokal, nama daerah dan sebagainya.

\section{Metode}

Kegiatan Pengabdian Pada Masyarakat ini dilaksanakan secara tim oleh dosen-dosen Program Studi Biologi Fakultas Sains dan Teknologi Universitas PGRI Palembang dengan tema umum "Teknik pembuatan herbarium bagi siswa SMAN 1 Pangkalan Lampam Ogan Komering Ilir”.

Kegiatan yang dilakukan berupa penyuluhan dan pelatihan langsung kepada guru-guru dan siswa di lingkungan SMAN 1 Pangkalan Lampam Ogan Komering

Ilir. Pelatihan dilaksanakan dalam enam tahapan seperti pada gambar berikut: 


\begin{tabular}{|c|c|}
\hline $\begin{array}{l}\text { TAHAP } 1 \\
\text { PERSIAPAN }\end{array}$ & $\begin{array}{l}\text { Tim pelaksana menyiapkan segala sesuatu untuk kegiatan PKM. Selain itu, } \\
\text { tim juga akan berkoordinasi ke mitra dalam rangka persiapan untuk } \\
\text { pelaksanaan kegiatan baik jadwal maupun persiapan alat dan bahan dalam } \\
\text { kegiatan. }\end{array}$ \\
\hline $\begin{array}{l}\text { TAHAP } 2 \\
\text { SOSIALISASI }\end{array}$ & $\begin{array}{l}\text { Tim pelaksana akan memberikan sosialisasi berupa gambaran } \\
\text { kegiatan PKM yang akan dilaksanakan kepada siswa. Kegiatan ini } \\
\text { dilaksanakan dengan metode ceramah, tanya jawab dan praktek langsung. }\end{array}$ \\
\hline $\begin{array}{l}\text { TAHAP } 3 \\
\text { PELATIHAN }\end{array}$ & $\begin{array}{l}\text { Pada tahap ini dilaksanakan dalam bentuk pelatihan. Materi pelatihan yaitu mulai } \\
\text { dari pengumpulan bahan, pengeringan, identifikasi, deskripsi, klasifikasi, penamaan } \\
\text { dan labeling. }\end{array}$ \\
\hline $\begin{array}{l}\text { TAHAP } 4 \\
\text { Pengecekan hasil }\end{array}$ & $\begin{array}{l}\text { Tim pelaksana PKM akan mengecek perkembangan tahapan pembuatan } \\
\text { herbarium. Pada tahap ini diharapkan siswa sudah paham dan terampil. }\end{array}$ \\
\hline $\begin{array}{l}\text { TAHAP } 5 \\
\text { EMALUASI }\end{array}$ & Siswa telah memahami tujuan dari pembuatan herbarium \\
\hline $\begin{array}{c}\text { TAHAP } 6 \\
\text { REFLEKSI KEGIA }\end{array}$ & $\begin{array}{l}\text { Tim pelaksana dan peserta akan berdiskusi tentang sejauh mana tingkat } \\
\text { keberhasilan program, kendala atau masalah yang dihadapai selama kegiatan } \\
\text { berlangsung, dan saran serta tindak lanjut setelah }\end{array}$ \\
\hline
\end{tabular}

Gambar 1. Tahapan Pelaksanaan Kegiatan

\section{Hasil dan Pembahasan}

Peserta kegiatan pengabdian kepada masyarakat ini diikuti oleh guru-guru dan siswa di lingkungan SMA Negeri 1 Pangkalan Lampam. Penyuluhan dan pelatihan yang dilaksanakan ini merupakan pelatihan dasar yang diberikan kepada peserta dalam waktu yang relatif singkat, sehingga penyampaian materi dirasa belum maksimal. Diperlukan durasi pelatihan yang lebih lama agar para peserta dapat lebih mendalami berbagai hal yang bisa dilakukan dengan berbagai koleksi tumbuhan.

Berdasarkan tahapan-tahapan kegiatan yang telah dilaksanakan, siswa dapat mengerti prinsip dasar kegiatan taksonomi tumbuhan. Mulai dari inventarisasi, deskripsi, identifikasi sampai pengeringan penamaan. Ada dua jenis herbarium antara lain: Herbarium basah adalah awetan dari hasil eksplorasi yang sudah diidentifikasi dan ditanam bukan lagi di habitat aslinya. Herbarium kering adalah awetan yang dibuat dengan cara dikeringkan, namun masih bisa terlihat ciri-ciri morfologinya sebagaimana dikemukakan Silalahi dan Nisyawaty (2015).[2]

Tahapan dalam pembuatan herbarium yang dilakukan mengikuti Rosanti (2016) dan Tjitrosoepomo (2015)[3] yaitu :

\subsection{Pengumpulan}

Tahap ini dilakukan dengan cara eksplorasi lapangan. Ambilah terutama dari bagian tumbuhan yang berbunga atau malahan yang berbuah. Buatlah sedikitnya 2 sampel yang lengkap dari tiap jenis. Bagian dari tumbuhan yang besar sedikitnya panjangnya $\mathrm{cm}$ dan sedikitnya harus ada satu daun dan satu inflorescencia yang lengkap, kecuali kalau bagiannya yang khusus masih terlalu besar. Lihatlah bagian tumbuhan yang berada dibawah tanah. Sediakan buku untuk mencatat kehususan seperti : warna, bau, bagian dalam tanah, tinggi tempat dari permukaan laut, tempat, banyaknya tanaman tersebut.

3.2. Tahap Pengeringan

Tahap ini dilakukan dengan cara eksplorasi lapangan. Ambilah terutama dari bagian tumbuhan yang berbunga atau malahan yang berbuah.

$\overline{\text { Inka Dahlianah......................Teknik Pembuatan Herbarium Bagi Siswa }}$ 
Buatlah sedikitnya 2 sampel yang lengkap dari tiap jenis. Bagian dari tumbuhan yang besar sedikitnya panjangnya $\mathrm{cm}$ dan sedikitnya harus ada satu daun dan satu inflorescencia yang lengkap, kecuali kalau bagiannya yang khusus masih terlalu besar. Lihatlah bagian tumbuhan yang berada dibawah tanah. Sediakan buku untuk mencatat kekhususan seperti : warna, bau, bagian dalam tanah, tinggi tempat dari permukaan laut, tempat banyaknya tanaman tersebut.

3.3. Tahap Pengawetan

Tanaman yang dikeringkan selalu bersifat hygroscopis, akan mudah sekali terserang jamur. Oleh karena itu, usahakanlah penyimpanan herbarium di tempat kering dan jemurlah koleksi tersebut sekali-kali dibawah sinar matahari. 3.4. Tahap labeling

Berisi keterangan-keterangan tentang tumbuhan tersebut diletakkan di sudut kiri bawah atau sudut kanan bawah Spesimen dipisahkan sesuai dengan kelompoknya kemudian diidentifikasi. Dianjurkan membuat lembar label kosong untuk kemungkinan perubahan nama. 3. Pengasapan dan peracunan (Fumigasi) Sebelum memasukkan spesimen ke herbarium terlebih dahulu harus diasap dengan carbon bisulfida dalam ruangan tertentu. Metode lain dapat dilakukan dengan menambahkan kristal paradiklorobenzen. Umumnya herbarium-herbarium melakukan fumigasi dengan interval 1, 2, 3 tahun. Umumnya spesimen disusun ke dalam kotak atau lemari khusus berdasarkan alphabet.

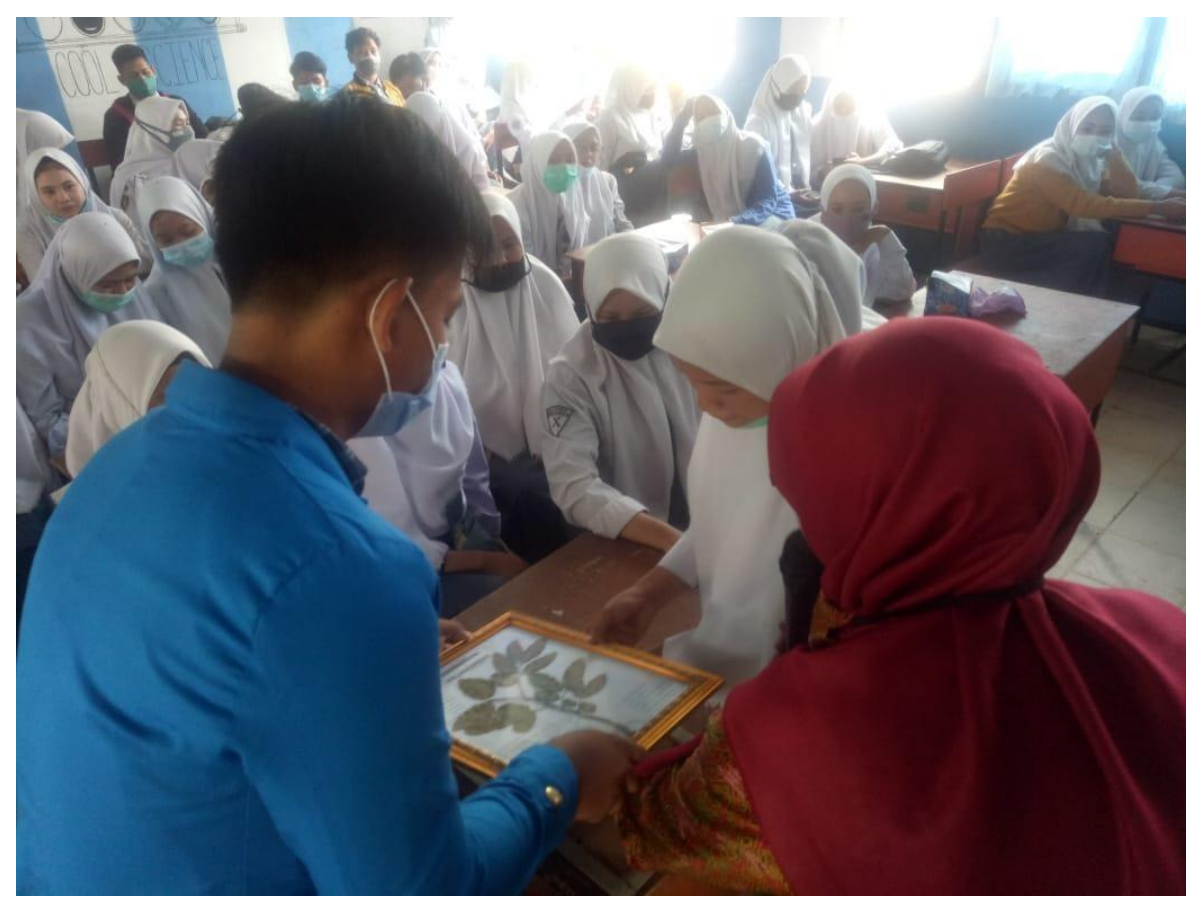

Gambar 2. Pengemasan herbarium untuk dipasarkan sebagai entrepreneur

\section{Kesimpulan}

Berdasarkan hasil pelatihan yang telah dilaksanakan, dapat disimpulkan bahwa penerapan teknik pembuatan herbarium sangat baik untuk dikembangkan di kalangan siswa SMA, sebagai penerapan ilmu pengetahuan, teknologi dan kewirausahaan menghadapi dunia kerja terutama di masa pandemi covid-19.

Teknik Pembuatan Herbarium Bagi Siswa..................... Inka Dahlianah 


\section{Ucapan terima kasih}

Dalam kesempatan ini ucapan terima kasih kami tujukan kepada Rektor Universitas PGRI Palembang yang telah mendukung kegiatan ini, baik secara moril dan materil. Juga kepada Kepala SMA Negeri 1 Pangkalan Lampam beserta seluruh pegawai dan siswa, yang mendukung penuh pelaksanaan kegiatan Tri Darma Perguruan Tinggi bagi Dosen Program Studi Biologi Fakultas Sains dan Teknologi Universitas PGRI Palembang.

\section{Daftar pustaka}

[1] D. Rosanti, "Jenis-Jenis Gulma pada Perkebunan Karet Desa Tanah Abang Kabupaten Muara Enim Provinsi Sumatera Selatan," J. Sainmatika, vol. 8, no. 2, 2012.

[2] M. Silalahi dan Nisyawati, "Etnobotani Pasak Bumi (Eurycoma longifolia Jack.) Pada Etnis Batak Sumatera Utara," in Makalah pada Seminar Nasional Masyarakat Biodiversitas Indonesia, 2015.

[3] G. Tjitrosoepomo, Taksonomi Spermatophyta. Yogyakarta: Gadjah Mada University Press, 2010.

[4] M. Indrawan, R. B. Primack, dan J. Supriatna, Biologi Konservasi. Jakarta: Yayasan Obor Indonesia, 2007.

[5] K. Kartawinata, "Dua Abad Mengungkap Kekayaan Flora dan Ekosistem Indonesia," in Sarwono Prawirohardjo Memorial Lecture X, Jakarta: LIPI, 2010, hal. 1-38.

$\overline{\text { Inka Dahlianah......................Teknik Pembuatan Herbarium Bagi Siswa }}$ 